\title{
Predicting multi-species foraging hotspots for marine turtles in the Gulf of Mexico
}

\author{
Ikuko Fujisaki ${ }^{1, *}$, Kristen M. Hart ${ }^{2}$, David Bucklin ${ }^{1}$, Autumn R. Iverson ${ }^{3}$, \\ Cynthia Rubio ${ }^{4}$, Margaret M. Lamont ${ }^{5}$, Raul de Jesus Gonzales Diaz Miron ${ }^{6}$, \\ Patrick M. Burchfield ${ }^{7}$, Jaime Peña ${ }^{7}$, Donna J. Shaver ${ }^{4}$ \\ ${ }^{1}$ University of Florida, Ft. Lauderdale Research and Education Center, Davie, FL 33314, USA \\ ${ }^{2}$ US Geological Survey, Wetland and Aquatic Research Center, Davie, FL 33314, USA \\ ${ }^{3}$ University of California, Davis, CA 95616, USA \\ ${ }^{4}$ National Park Service, Padre Island National Seashore, Corpus Christi, TX 78480, USA \\ ${ }^{5}$ US Geological Survey, Wetland and Aquatic Research Center, Gainesville, FL 32653, USA \\ ${ }^{6}$ Acuario de Veracruz A.C., Veracruz, Veracruz 91900, Mexico \\ ${ }^{7}$ Gladys Porter Zoo, Brownsville, TX 78520, USA
}

\begin{abstract}
Quantifying the distribution of animals and identifying underlying characteristics that define suitable habitat are essential for effective conservation of free-ranging species. Prioritizing areas for conservation is important in managing a geographic extent that has a high level of disturbance and limited conservation resources. We examined the potential use of a species distribution model ensemble for multi-species conservation in marine habitats. Using satellite telemetry locations during foraging as input data, and ensemble ecological niche models, we predicted foraging areas for 2 nesting marine turtle species within the Gulf of Mexico (GoM): Kemp's ridley Lepidochelys kempii $(\mathrm{n}=63)$ and loggerhead Caretta caretta $(\mathrm{n}=63)$. We considered 7 geophysical, biological, and climatic variables and compared contributing factors for each species' foraging habitat selection. For both species, predicted suitable foraging habitats encompassed large areas along the GoM coast, but only intersected with each other in relatively small areas. Highly parameterized models resulted in overall greater fits, suggesting that multiple factors influence habitat selection by these species. Model validation results were mixed: cross-validation resulted in high prediction accuracy for both species, but an evaluation against independent data resulted in a low omission rate $(5 \%)$ for Kemp's ridleys and a high omission rate $(72 \%)$ for loggerheads. The relatively small intersection of model-predicted foraging areas for these 2 species within the study area may indicate possible niche differentiations. The high omission rate for loggerheads indicates our samples likely underrepresent the population and illustrates the challenges in predicting suitable foraging extents for species that make dynamic movements and have greater individual variability.
\end{abstract}

KEY WORDS: Ensemble ecological niche model - Foraging - Gulf of Mexico - Habitat . Kemp's ridley · Loggerhead · Species distribution model

\section{INTRODUCTION}

Intensifying modifications to wildlife habitat by humans is a primary factor causing losses of biodiversity (Soulé 1991) through decreases in number of species (McKee et al. 2004) and reduction of

*Corresponding author: ikuko@ufl.edu geographic extent (Chape et al. 2005). Therefore, allocating limited conservation resources towards protecting high-priority areas or biodiversity 'hotspots' is essential (Myers et al. 2000, Wilson et al. 2006). Identifying priority areas is an important first step (Wilson et al. 2006) and the spatial distribution

() The authors 2020. Open Access under Creative Commons by Attribution Licence. Use, distribution and reproduction are unrestricted. Authors and original publication must be credited. 
of imperiled free-ranging animals, such as threatened and endangered species, could be useful for improving conservation efficiency (Dobson et al. 1997).

Marine turtles are large vertebrates with high conservation needs; nearly all marine turtle species are threatened or endangered (Wallace et al. 2011). Because of their conservation status and considerable impact on marine resources through foraging and nutrient transfer, understanding their habitat use is important to maintain biodiversity (Bjorndal \& Jackson 2003) and is critical for successful conservation of marine ecosystems (Griffin et al. 2013, Stokes et al. 2015). However, their high mobility, aquatic nature, and distinctly different-and often geographically separate - behavioral modes (such as foraging, nesting, or migration periods) make it challenging to generalize their habitat use.

Collecting data on suitable habitat for species over large spatial extents can be logistically difficult, especially for species that range widely, such as marine turtles. During the last 2 decades, biotelemetry techniques have greatly improved our knowledge of in-water movements of marine turtles and by coupling this technique with quantitative models, their habitat use during different behavioral states has been described in many oceanic areas (Jonsen et al. 2007, Godley et al. 2008). However, studies using tracking data from tagged individuals have inherent limitations in predicting the 'big picture' of an entire population over a large geographic extent.

Species distribution models (SDM, also called niche modeling) are frequently used to predict the distribution of target species based on habitat relationships inferred from species occurrence (Guisan \& Zimmermann 2000, Elith \& Leathwick 2009, Franklin 2013). Because of their cost effectiveness, which makes use of presence-only data, and the increasing availability of computational resources, this is a rapidly progressing research area and numerous studies have documented methodological advances, validation methods, and case studies for various taxa (see Elith \& Leathwick 2009 for review; Pike 2013, 2014, Pollock et al. 2014, Pikesley et al. 2015, Mazor et al. 2016, Grüss et al. 2018, Winton et al. 2018 for sea turtles). Use of SDM allows us to create spatially explicit predictions of potentially suitable habitat for our entire area of interest by extrapolating predictions based on the location data of telemetered individuals. The idea of employing such a biogeographical approach has been extended to identify high-use areas for multi-species conservation (Boykin et al. 2008, Piacenza et al. 2015).
One of the major concerns in applying SDM is the uncertainty in predictions sourced from input data and modeling approaches (Dormann et al. 2008, Elith et al. 2009). Studies indicate that the modeling algorithm could contribute the greatest uncertainty (Dormann et al. 2008, Watling et al. 2015); therefore, studies used inferences from multiple modeling approaches by combining algorithms from different classes to make more robust predictions (Araújo \& New 2006). For example, the use of ensemble ecological niche modeling (EENM) has been demonstrated for marine habitat conservation by identifying foraging areas for olive ridley Lepidochelys olivacea and loggerhead sea turtles Caretta caretta and then linked predicted areas to human activities (Pikesley et al. 2013, 2015).

In this study, we apply EENM using satellite telemetry locations as input data to predict suitable foraging habitat for 2 sea turtle species in the Gulf of Mexico (GoM), whose post-nesting migration patterns are different: Critically Endangered Kemp's ridleys $L$. kempii and federally threatened loggerheads. Our goal was to provide the foundation for multi-species marine habitat conservation. Specifically, we delineated the spatial extent of suitable foraging habitat for adult female Kemp's ridleys and loggerheads in the GoM, identified critical environmental characteristics that determine these extents, and validated the predictions.

\section{MATERIALS AND METHODS}

\subsection{Satellite telemetry data}

We used Argos satellite-derived locations for adult female Kemp's ridleys $(n=63)$ and loggerheads $(n=$ 63) during foraging periods that were previously identified using switching state-space modeling (SSM) (Shaver et al. 2013, 2016a, Hart et al. 2014). Tagging (nesting) sites of Kemp's ridleys were Padre Island National Seashore, TX, USA $(n=41)$, Tecolutla, Veracruz, Mexico $(\mathrm{n}=11)$, Rancho Nuevo, Tamaulipas, Mexico $(\mathrm{n}=10)$, and Gulf Shores, AL, USA $(n=1)$, and those of loggerheads were Gulf Shores, AL ( $\mathrm{n}=30)$, St. Joseph Peninsula, FL $(\mathrm{n}=16)$, Dry Tortugas National Park (DRTO), FL $(\mathrm{n}=15)$, and Eglin Air Force Base, FL, USA ( $n=2$, Fig. 1). We tagged and outfitted loggerhead and Kemp's ridley females with satellite transmitters after they nested throughout the GoM. All tagging followed established protocols (NMFS SEFSC 2008). We tagged each animal with a passive integrated transponder (PIT) tag in the right 


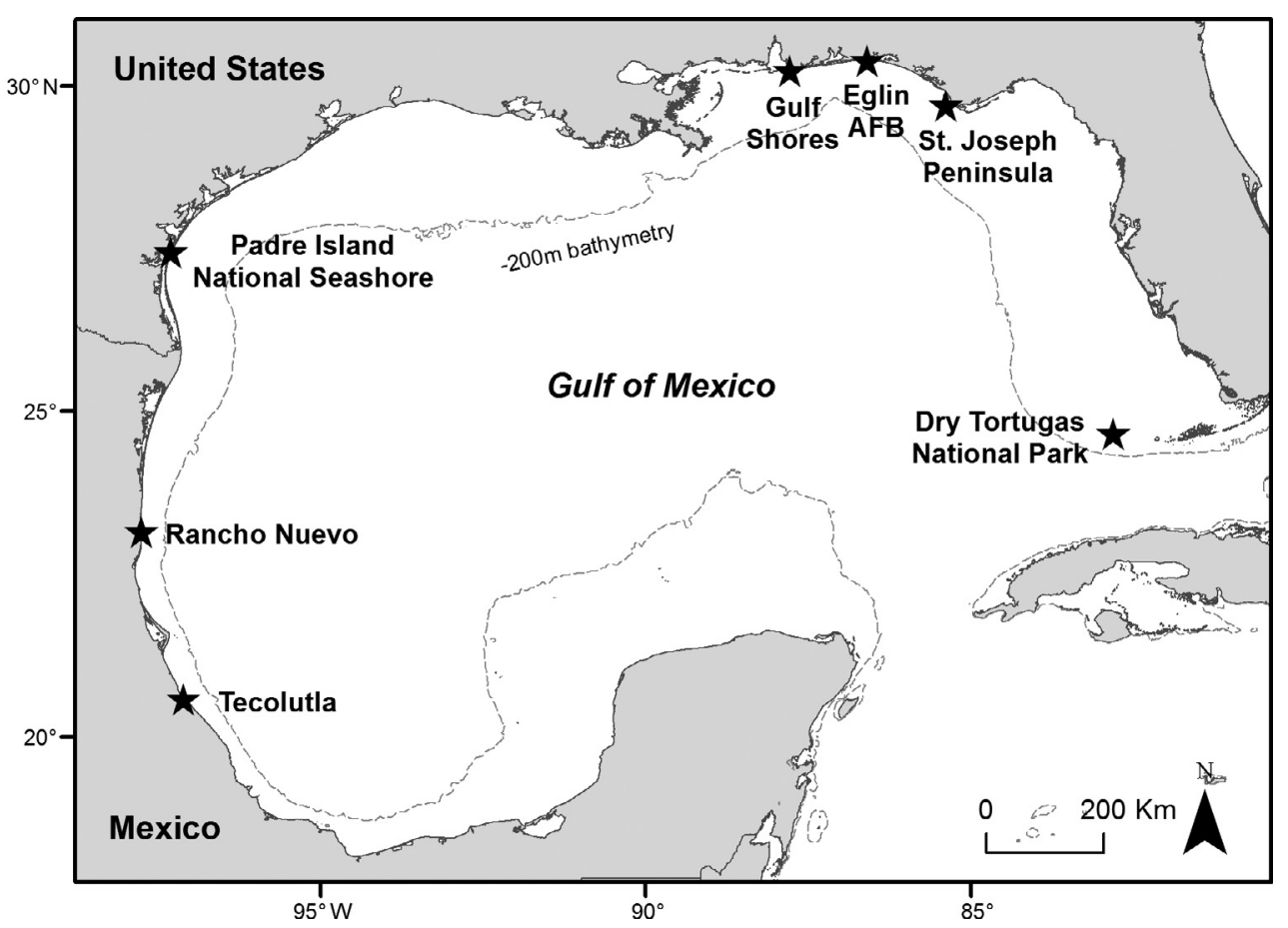

Fig. 1. Tagging locations ( $\star$ ) for satellite-tracked turtles in the Gulf of Mexico. Kemp's ridleys were tagged in Mexico at Tecolutla, Veracruz $(\mathrm{n}=11)$ and Rancho Nuevo, Tamaulipas $(\mathrm{n}=10)$ and in the USA at Padre Island National Seashore, TX $(\mathrm{n}=41)$ and Gulf Shores, AL $(n=1)$. Loggerheads were tagged in the USA at Gulf Shores, AL $(n=30)$ and St. Joseph Peninsula $(n=16)$, Dry Tortugas National Park $(n=15)$, and Eglin Air Force Base (AFB) $(n=2)$, FL

shoulder (loggerhead) or left flipper (Kemp's ridley), and affixed an individually numbered flipper tag to each of the front flippers (loggerhead), or the left front and left rear flipper (Kemp's ridley). Immediately after tagging each animal, we took standard carapace measurements, including curved (CCL) and straight (SCL) carapace lengths. We fitted a platform terminal transmitter (PTT) to each turtle. Prior to transmitter application with either Power-Fast ${ }^{\mathrm{TM}}$ or SuperBond ${ }^{\mathrm{TM}}$ 2-part cool-setting marine epoxies (loggerhead), or fiberglass cloth and resin (Kemp's ridley), we removed epibionts (e.g. barnacles, algae) from the carapace of each turtle and sanded and cleaned the carapace with isopropyl alcohol. We streamlined attachment materials and minimized the application footprint. For loggerheads, the anticipated battery life of each tag was $1 \mathrm{yr}$, and each tag in 2008, 2009, and 2010 was programmed to operate continuously; in 2011, 2012, and 2013, we adjusted winter tracking (November through April) to every 3rd day to prolong battery life. For Kemp's ridleys, some PTTs were programmed with a transmission cycle of 6-h-on:6-h-off, and some were programmed to operate continuously. Tagged turtles were released within 3-4 h at their capture location.

\subsection{Switching state-space model}

We used switching SSM (Jonsen et al. 2003, Patterson et al. 2008) to characterize the movements of all turtles. The model was described in 2005 (Jonsen et al. 2005) and has previously been applied to the movement of marine animals, including turtles (e.g. Bailey et al. 2008). Location data obtained through satellite transmitters are received at irregular time intervals and sometimes involve large temporal gaps and positional errors. Ad hoc filtering of location data based on location quality is insufficient to remove erroneous locations and also results in loss of information (Jonsen et al. 2006). Switching SSM estimates location and behavioral mode at regular time intervals, accounting for satellite positional errors and dynamics of the animal movement pattern (Jonsen et al. 2005) and is a recommended analytical technique for Argos tracking data once post-processed by removing land points and adding back in good Argos locations (Hoenner et al. 2012).

We used the switching SSM approach to determine dates of each turtle at its foraging ground(s) following Hart et al. (2012) and Shaver et al. (2013). The behav- 
ioral mode was binary, defined as 'foraging' and 'migration' as in earlier applications (Jonsen et al. 2005, 2007, Breed et al. 2009). However, since we tagged animals during nesting seasons, we defined the behavioral mode as 'foraging and/or nesting' and 'migration'. We summarized data for the periods after a migration, unless high-quality locations on land indicated the turtle was still in the inter-nesting period. We applied a model used by Breed et al. (2009), which is a modified version of a model described by Jonsen et al. (2005) that estimates model parameters by Markov chain Monte Carlo (MCMC) using WinBUGS via the software program $\mathrm{R}$. We fit the model to tracks of each individual turtle to estimate location and behavioral mode every $8 \mathrm{~h}$ from 2 independent and parallel chains of MCMC. Our samples from the posterior distribution were based on 10000 iterations after a burn-in of 7000 and thinned by 5 . With the beginning and end dates for foraging periods determined by SSM, we used original, filtered satellite locations from within those time periods for further analysis.

We considered Argos locations during SSM-identified foraging periods to be biologically plausible if they were retained after passing through a speed and topography filter; that is, we removed locations that were on land, extremely distant, or with speeds $>5 \mathrm{~km} \mathrm{~h}^{-1}$ (Mansfield et al. 2009). Each Argos satellite location is associated with a location class (LC) which is an indicator of location accuracy. We used the 3 highest LCs $(3,2,1)$ for this study, and only used the lower LC locations for pseudo-absence filtering (explained in Section 2.4). We also removed locations with bathymetry values deeper than $200 \mathrm{~m}$ (neritic zone cutoff). Adult female loggerheads in the southeast USA do not generally leave the waters of the continental shelf (within 200 m) (Hawkes et al. 2007) and previous tracking studies of Kemp's ridleys show turtles stay primarily within the $100 \mathrm{~m}$ isobath (Shaver \& Rubio 2008, Seney \& Landry 2011). For all tracks in this study with potential foraging periods, the locations removed based on the bathymetry accounted for $<1 \%$ of available locations after speed filtering (68 of 58465 speed-filtered locations).

\subsection{Environmental data}

Following Pikesley et al. (2015), who predicted habitat of post-nesting loggerheads, we considered bathymetric depth (m) (www.ngdc.noaa.gov/mgg/ global/, accessed Apr 8, 2014), monthly averaged MODIS L3 night-time sea surface temperature (SST: $\left.{ }^{\circ} \mathrm{C}\right)$ (http://podaac.jpl.nasa.gov, accessed Feb 6, 2015), net primary production (NPP: mg C $\mathrm{m}^{2} \mathrm{~d}^{-1}$ ) (www. science.oregonstate.edu/ocean.productivity, accessed Feb 10, 2015), sea surface current velocity $\left(\mathrm{m} \mathrm{s}^{-1}\right)$ (https://hycom.org, accessed Feb 6, 2015), and ocean frontal activity (derived from MODIS SST data using the single image edge detection [SIED] algorithm; Cayula \& Cornillon 1992). Raster data of SST, sea surface current velocity, and ocean frontal activity data were downloaded using the Marine Geospatial Ecology Tools extension for ArcGIS (Roberts et al. 2010). We also considered the present Bio-ORACLE data (Tyberghein et al. 2012, www.bio-oracle.org, accessed Jan 29, 2015), an array of 5 arcminute resolution (approximately $9.2 \mathrm{~km}$ ) monthly geophysical, biotic, and climate rasters, as these could be additional explanatory factors of marine turtle foraging habitats. In particular, cloud cover may be related to various important ecological processes such as reproduction, growth, survival, and behavior (Wilson \& Jetz 2016), and silicate amount could be an indicator of turtle foraging habitat, as turtles may forage for shellfish in muddy bottoms. To accurately assess the contribution of each input variable, we assessed bivariate correlations between the variables in grid cells that contain observed locations and selected a set of 7 variables that were not correlated strongly $(|\mathrm{r}|<0.5)$ to use for modeling. Bivariate correlations between the variables are included in Table S1 in the Supplement at www.int-res.com/ articles/suppl/n043p253_supp.pdf.

\subsection{Ensemble modeling, model validation, and model selection}

Referring to Pikesley et al. (2015), we parameterized 3 modeling algorithms for EENM using $\mathrm{R}$ package biomod2 (Thuiller et al. 2016): (1) the parametric generalized linear model (GLM), (2) the machine learning algorithm MaxEnt (Phillips et al. 2006), and (3) the nonparametric multivariate adaptive regression splines (MARS). The GLM was implemented with a quadratic formula and logit link function, with an interaction level of zero, and the Akaike information criteria (AIC) as a stepwise selection procedure (Thuiller et al. 2016). The MARS model was parameterized with a maximum interaction degree of 2 , a penalty (cost per degree of freedom change) of 2 , a forward stepwise process with a stopping threshold of 0.001 , and pruning with a backward stepwise method. For MaxEnt, 200 iterations were used, and all feature function types (linear, quadratic, product, threshold, and hinge) were allowed (as in all cases, presence sample size was above $\mathrm{n}=80$ ). All regularization parameters were set automatically, and 
default prevalence (probability of presence at occurrence points) was 0.5 . Due to relatively large bathymetric variability in neritic zones compared to climate variables, predictions were made in each grid cell, sized to match the bathymetry raster (with side lengths of 0.0167 decimal degrees, equivalent to $\sim 1.7 \times 1.7 \mathrm{~km}$ ), and covered the entire GoM. We created an ensemble model by averaging the continuous (probability) prediction values across the 3 individual models (GLM, MaxEnt, and MARS). To create binary predictions, we used a threshold method, maximizing the true skill statistic (TSS; equal to the sum of sensitivity and specificity minus 1; Allouche et al. 2006) on the full presence/pseudo-absence dataset when presenceonly data were used. This method was applied to each of the individual models, as well as to the ensemble model (Liu et al. 2013).

To calibrate and evaluate the results from EENM, we took a random subset of approximately $20 \%$ of the turtles from each species $(\mathrm{n}=12$, Kemp's ridley; $\mathrm{n}=12$, loggerhead) for independent validation of model predictions. Locations from the remaining turtles ( $\mathrm{n}=51$ of each species) were split into training (80\% of the locations) and cross-validation (20\%) at each iteration of a bootstrap sample (random sample with replacement) for 10 repetitions, in which the prediction was validated at each iteration. We removed duplicate occurrence locations in each grid cell and generated pseudo-absence locations within $200 \mathrm{~m}$ isobaths. By default, pseudo-absences were not created in cells with presence locations; in addition, we did not allow pseudo-absence in cells where presences not used in the model (lower-quality locations where LC was not 3, 2, or 1) were found to ensure the absence of tagged turtles.

We used 3 model performance metrics in the crossvalidation calculated with biomod2: area under the curve (AUC) of a receiver operating characteristic (Fielding \& Bell 1997), Cohen's kappa ( $\kappa)$, and the TSS. For evaluation of AUC values, we used the following criteria: the model is excellent if AUC $>0.90$, good if $0.80<$ AUC $<0.90$, fair if $0.70<$ AUC $<0.80$, poor if $0.60<\mathrm{AUC}<0.70$, and fails if $0.50<\mathrm{AUC}<$ 0.60 (Swets 1988). For evaluation of kappa, we used criteria by Fleiss \& Cohen (1973), that is, the agreement of prediction and validation is excellent if $\kappa>$ 0.75 , fair to good if $0.40<\kappa<0.75$, and poor if $\kappa<$ 0.40. For evaluation of TSS values, we followed the criteria: excellent if TSS $>0.75$, good if $0.40<$ TSS $<$ 0.75, and poor if TSS $<0.40$ (Landis \& Koch 1977). Using independent validation data, we calculated the omission rate, which is defined as the number of observed locations that occurred where the pre- dicted probability was below the threshold divided by the total number of occurrence locations.

The permutation importance of EENM for each variable was calculated using biomod2. Briefly, this method compares the original model predictions to those made with a new model where the values of the variable of interest are randomly permutated, and calculates Pearson's correlation (r) between the 2 models' predictions for the training dataset. The variable of importance is then calculated as $1-\mathrm{r}$. We then averaged permutation importance across the 10 cross-validation runs. Using the combination of environmental variables which had high relative importance based on the results of full models, we created a list of candidate models and ran these models for each algorithm with the full calibration dataset. For GLM and MaxEnt algorithms, we estimated AIC, $\triangle \mathrm{AIC}$, and AIC weight, and identified the best predictive model for each species. We considered models in which $\triangle \mathrm{AIC}<2$ to be equivalent to the best-fitting model (Burnham \& Anderson 2002). For MARS, we used mean square error of prediction (MSEP) as an indicator for model fit.

\section{RESULTS}

\subsection{Satellite locations and environmental variables}

In total, we had 51986 satellite locations with LC 3, 2, or 1 from 126 tagged turtles. For Kemp's ridleys, we had 2196 non-duplicated locations in the cells, and these were split for training and cross-validation $(\mathrm{n}=1400)$ and validation from the 12 random subset turtles ( $\mathrm{n}$ = 796). For loggerheads, 1562 non-duplicated locations in the cells were used for training and cross-validation $(\mathrm{n}=1282)$ and validation $(\mathrm{n}=280)$ with the 12 randomly selected turtles (Fig. 2).

A number of environmental variables we initially considered were highly correlated. After removing these correlated variables, we used 7 environmental variables for EENM, including 5 variables used by Pikesley et al. (2015) and 2 Bio-ORACLE variables: (1) bathymetry, (2) SST, (3) NPP, (4) current velocity, (5) ocean frontal activity, (6) silicate amount ( $\mu m o l$ $\left.1^{-1}\right)$, and (7) cloud cover (\%).

\subsection{Predicted areas}

The predicted suitable habitats for both species spanned the entire GoM coast, but most of the pre- 


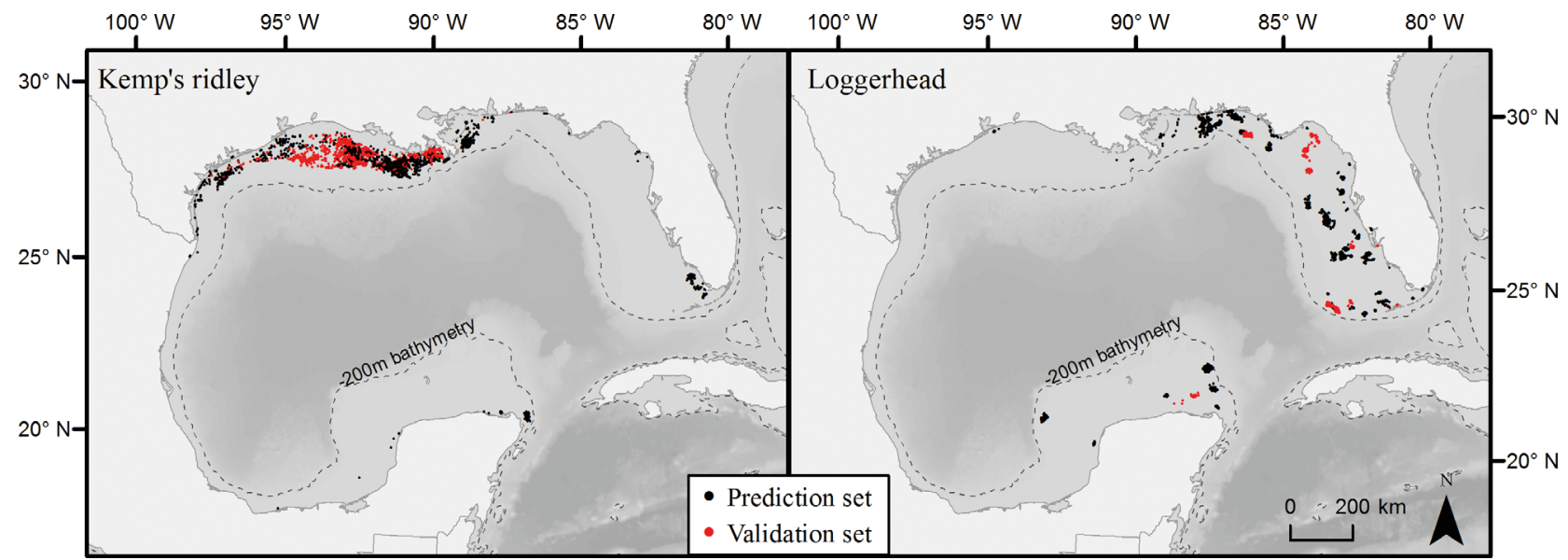

Fig. 2. Satellite-derived foraging locations for Kemp's ridley (left panel) and loggerhead (right panel) turtles used for training and cross-validation (prediction set) and validation

dicted foraging areas for Kemp's ridleys and loggerheads did not intersect (Fig. 3). Suitable habitat for Kemp's ridleys was located primarily along the coast between northern Mexico and Alabama, USA, whereas that of loggerheads ranged from Alabama to southwestern Florida, USA. Potential multi-species foraging areas - where predicted suitable foraging areas intersected for the 2 species - were along the northern GoM coast between Louisiana and Alabama, USA, as well as the along the coasts of western Florida and the Yucatán Peninsula, Mexico. The predicted suitable habitats from individual models
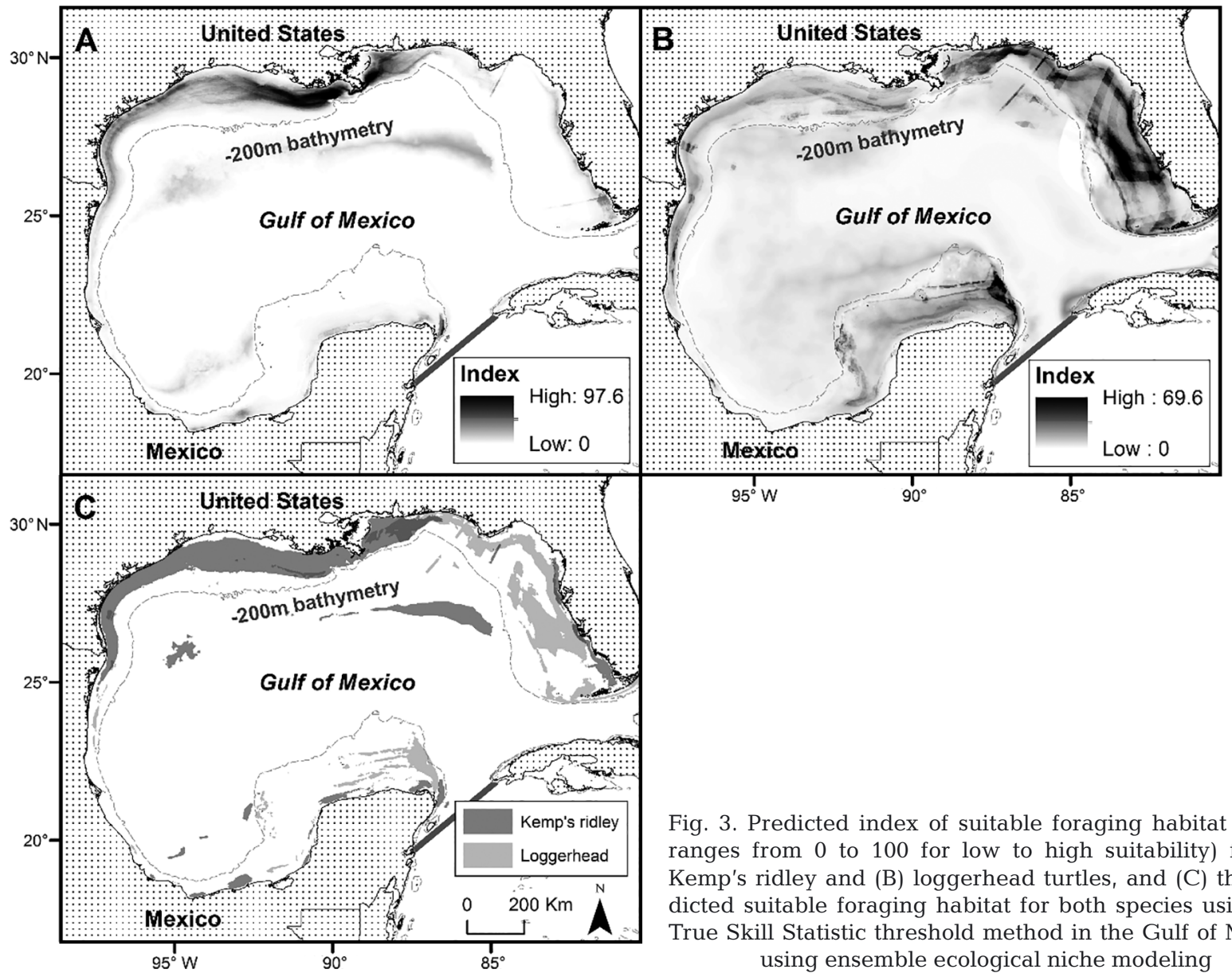

Fig. 3. Predicted index of suitable foraging habitat (index ranges from 0 to 100 for low to high suitability) for (A) Kemp's ridley and (B) loggerhead turtles, and (C) the predicted suitable foraging habitat for both species using the True Skill Statistic threshold method in the Gulf of Mexico using ensemble ecological niche modeling 
(Fig. 4) were highly variable. MaxEnt resulted in the most conservative prediction (smaller area), and those by GLM were intermediate (Fig. 4).

\subsection{Model validation}

Results from the cross-validations for the EENM indicated a high accuracy for predicted foraging areas. The mean AUC for both species (0.95 for Kemp's ridley and 0.90 for loggerhead) indicated an excellent accuracy of discrimination (Table 1). The kappa statistics indicated that there were good agreements between prediction and cross-validation data for both species $(\kappa=0.66$ for Kemp's ridleys and $\kappa=0.58$ for loggerheads). The predictive performance based on TSS was excellent for Kemp's ridleys (0.80) and it was good for loggerheads (0.68).

The results of model evaluations with independent datasets (satellite locations of the subset of turtles whose locations were not used for modeling) were distinctly different for the 2 species. The proportion of locations that correctly predicted the occurrence of Kemp's ridleys was 0.95, suggesting a low omission rate $(0.05)$ (Table 2$)$. The mean omission rate of individual Kemp's ridley data was $0.07(\mathrm{SD}=0.17)$ and

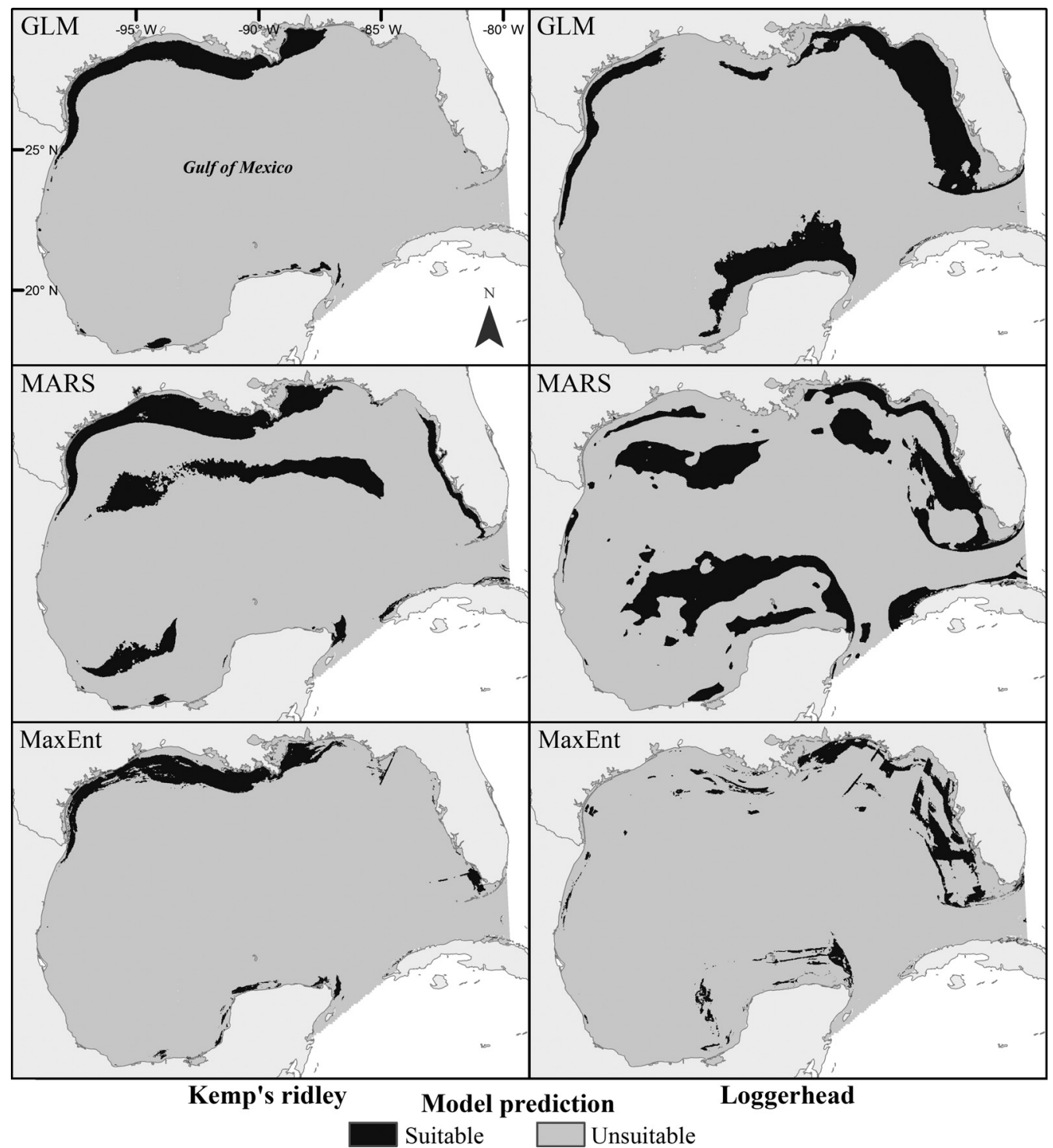

Fig. 4. Threshold model prediction by 3 models, generalized linear model (GLM), multivariate adaptive regression splines (MARS), and MaxEnt, used for the ensemble ecological niche model for adult female Kemp's ridley and loggerhead turtles that nested in the Gulf of Mexico 
Table 1. Model evaluations of predictions by ensemble ecological niche modeling based on 10-fold cross-validations by area under the curve (AUC), kappa statistics, and true skill statistics (TSS) for Kemp's ridley and loggerhead turtles that nested along the Gulf of Mexico

\begin{tabular}{|c|c|c|c|c|c|c|}
\hline \multirow{2}{*}{$\begin{array}{l}\text { Evaluation } \\
\text { method }\end{array}$} & \multirow{2}{*}{\multicolumn{3}{|c|}{$\begin{array}{l}\text { Kemp's ridley } \\
\text { Mean Sensitivity Specificity }\end{array}$}} & \multicolumn{3}{|c|}{$\ldots$ Loggerhead } \\
\hline & & & & Mean & Sensitivity & Specificity \\
\hline AUC & 0.95 & 93.68 & 86.16 & 0.90 & 83.28 & 84.87 \\
\hline Карра & 0.66 & 73.32 & 95.16 & 0.58 & 63.91 & 94.83 \\
\hline TSS & 0.80 & 93.61 & 85.96 & 0.68 & 83.59 & 84.22 \\
\hline
\end{tabular}

Table 2. Total and mean omission rate calculated using satellite locations from an independent subset of Kemp's ridley $(\mathrm{n}=12)$ and loggerhead $(\mathrm{n}=12)$ turtles which nested along the Gulf of Mexico

\begin{tabular}{|lccccc|}
\hline Species & Total & Mean & SD & Min & Max \\
\hline Kemp's ridley & 0.05 & 0.07 & 0.17 & 0.00 & 0.50 \\
Loggerhead & 0.72 & 0.76 & 0.36 & 0.00 & 1.00 \\
\hline
\end{tabular}

Table 3. Permutation importance (ranging from 0 to 1 for low to high) of predictor variables used for ensemble ecological niche modeling for Kemp's ridley and loggerhead turtles that nested along the Gulf of Mexico. NPP: net primary production; clouds: cloud cover, SST: sea surface temperature; silicate: silicate amount; depth: bathymetry depth; currents: ocean currents; front: ocean front

\begin{tabular}{|c|c|c|c|}
\hline \multirow{2}{*}{$\begin{array}{l}\text { Kemp's ridley } \\
\text { variable }\end{array}$} & \multicolumn{3}{|c|}{ - Loggerhead } \\
\hline & $\begin{array}{c}\text { Importance } \\
(\%)\end{array}$ & Variable & $\begin{array}{c}\text { Importance } \\
(\%)\end{array}$ \\
\hline NPP & 0.631 (52.9) & NPP & $0.315(21.6)$ \\
\hline Depth & $0.204(17.1)$ & Clouds & $0.285(19.7)$ \\
\hline SST & 0.164 (13.8) & SST & $0.276(19.0)$ \\
\hline Silicate & $0.100(8.4)$ & Silicate & $0.274(18.9)$ \\
\hline Currents & $0.075(6.3)$ & Depth & 0.158 (10.9) \\
\hline Front & $0.012(1.0)$ & Currents & $0.111(7.6)$ \\
\hline Clouds & $0.006(0.5)$ & Front & $0.031(2.1)$ \\
\hline
\end{tabular}

ranged from 0.00 to 0.50 , meaning that at least half of the locations were within the predicted foraging area for all individuals. The proportion of the correctly predicted locations for loggerheads, however, was 0.28 , indicating that the majority of occurrence locations $(72 \%)$ in the validation dataset were omitted. The average omission rate was $0.76(\mathrm{SD}=0.36)$ and ranged from 0.00 to 1.00 . Half of the loggerheads (6 of 12) foraged completely outside of the predicted areas.

\subsection{Variable importance and model selection}

The estimated importance of NPP was the highest among all 7 tested variables for both species, but the relative importance of NPP for the 2 species was different (Table 3): for Kemp's ridley, NPP was predominantly important (52.9\%), whereas for loggerhead, the importance of NPP $(21.6 \%)$ was similar to cloud cover $(19.7 \%), \operatorname{SST}(19.0 \%)$, and silicate amount (18.9\%; Table 3). For both species, the importance of SST was ranked 3rd, and the estimated relative importance, $13.8 \%$ for Kemp's ridley and $19.0 \%$ for loggerhead, was similar (Table 3). Relative importance of silicate amount, which was the 4 th important factor for both species, was distinctly different: its importance for loggerhead (18.9\%) was more than twice of that of Kemp's ridley (8.4\%). Ocean currents and ocean fronts had relatively small importance (1.0-7.6\%) for both species. Cloud cover, which was the 2nd most important variable for loggerheads, was the least important for Kemp's ridleys, with only $0.5 \%$ importance.

For model selection, we focused on 4 variables which had the greatest permutation importance for each species. Model selection using AIC and root mean square error (RMSE) revealed both similarity and inconsistency between species and between models (Table 4). In general, the results by GLM and MARS were consistent, whereas those by MaxEnt appeared different. For Kemp's ridleys, the top 2 models with GLM and MARS were the models with highest parameterizations, but these 2 models were the 2 worst-fit models according to MaxEnt (Table 4). With MaxEnt, the best-fitting model was the 3-variable model including NPP, SST, and silicate (Table 4). For loggerheads, the full model had the best fit when GLM and MARS were used, minimizing AIC and RMSE, but this model was ranked 10 with MaxEnt. The best model with MaxEnt included NPP, cloud cover, and silicate (Table 4).

\section{DISCUSSION}

It has been proposed that SDM should be an integral part of conservation and management decisionmaking (Guisan et al. 2013). Previous studies delineated foraging habitats for telemetered loggerheads and Kemp's ridleys within the neritic zone in the GoM (Shaver et al. 2013, Hart et al. 2014). The approach we used in the present study, which sought to identify the intersection of potential foraging habitats for Kemp's ridleys and loggerheads in the GoM based on EENM of 3 SDM algorithms, allowed us to 
Table 4. Model selections, Akaike information criteria (AIC), $\triangle \mathrm{AIC}$, AIC weight ( $\left.w_{\mathrm{i}}\right)$, root mean square error (RMSE), and rank of each model (ordered by AIC or RMSE from low to high), by 3 algorithms, generalized linear model (GLM), MaxEnt, and multivariate adaptive regression splines (MARS), to predict foraging areas for Kemp's ridley and loggerhead turtles that nested along the Gulf of Mexico. NPP: net primary production; clouds: cloud cover; SST: sea surface temperature; silicate: silicate amount; depth: bathymetry depth; currents: ocean currents; front: ocean front. -: not determined

\begin{tabular}{|c|c|c|c|c|c|c|c|c|c|c|}
\hline \multirow[t]{2}{*}{ Variables } & \multicolumn{4}{|c|}{ GLM } & \multicolumn{4}{|c|}{ MaxEnt } & \multicolumn{2}{|c|}{ MARS } \\
\hline & AIC & $\triangle \mathrm{AIC}$ & $W_{\mathrm{i}}$ & Rank & AIC & $\Delta \mathrm{AIC}$ & $W_{\mathrm{i}}$ & Rank & RMSE & Rank \\
\hline \multicolumn{11}{|l|}{ Kemp's ridley } \\
\hline NPP, clouds, SST, silicate, depth, currents, front & 4430 & 0 & 1.00 & 1 & 33475 & 3670 & 0.00 & 17 & 0.247 & 2 \\
\hline NPP, SST, silicate, depth, currents, front & 4451 & 21 & 0.00 & 2 & 33428 & 3623 & 0.00 & 16 & 0.245 & 1 \\
\hline NPP, depth, SST, silicate & 4731 & 301 & 0.00 & 3 & 30921 & 1116 & 0.00 & 7 & 0.250 & 3 \\
\hline NPP, depth, SST & 4973 & 543 & 0.00 & 5 & 31908 & 2103 & 0.00 & 10 & 0.260 & 6 \\
\hline NPP, depth, silicate & 4932 & 502 & 0.00 & 4 & 31345 & 1540 & 0.00 & 9 & 0.255 & 4 \\
\hline NPP, SST, silicate & 5297 & 867 & 0.00 & 7 & 29805 & 0 & 1.00 & 1 & 0.256 & 5 \\
\hline Depth, SST, silicate & 5613 & 1183 & 0.00 & 8 & 29944 & 139 & 0.00 & 2 & 0.261 & 7 \\
\hline NPP, depth & 5113 & 683 & 0.00 & 6 & 33076 & 3271 & 0.00 & 15 & 0.266 & 10 \\
\hline NPP, SST & 5986 & 1556 & 0.00 & 10 & 30585 & 780 & 0.00 & 5 & 0.270 & 11 \\
\hline NPP, silicate & 5702 & 1272 & 0.00 & 9 & 30542 & 737 & 0.00 & 4 & 0.266 & 9 \\
\hline Depth, SST & 6755 & 2325 & 0.00 & 13 & 31111 & 1305 & 0.00 & 8 & 0.288 & 13 \\
\hline Depth, silicate & - & - & - & - & 30379 & 574 & 0.00 & 3 & 0.275 & 12 \\
\hline SST, silicate & 6298 & 1868 & 0.00 & 11 & 30689 & 884 & 0.00 & 6 & 0.264 & 8 \\
\hline NPP & 6475 & 2045 & 0.00 & 12 & 32063 & 2258 & 0.00 & 11 & 0.296 & 15 \\
\hline Depth & 7487 & 3057 & 0.00 & 16 & 32911 & 3105 & 0.00 & 14 & 0.318 & 17 \\
\hline SST & 7347 & 2918 & 0.00 & 15 & 32725 & 2920 & 0.00 & 13 & 0.299 & 16 \\
\hline Silicate & 6954 & 2524 & 0.00 & 14 & 32553 & 2748 & 0.00 & 12 & 0.294 & 14 \\
\hline \multicolumn{11}{|l|}{ Loggerhead } \\
\hline NPP, clouds, SST, silicate, depth, currents, front & 6909 & 0 & 1.00 & 1 & 30021 & 2121 & 0.00 & 10 & 0.285 & 1 \\
\hline NPP, clouds, SST, silicate & 7180 & 271 & 0.00 & 2 & 29288 & 1388 & 0.00 & 6 & 0.287 & 3 \\
\hline NPP, clouds, SST & 7199 & 290 & 0.00 & 3 & 28616 & 716 & 0.00 & 3 & 0.295 & 5 \\
\hline NPP, clouds, silicate & 7249 & 340 & 0.00 & 4 & 27900 & 0 & 1.00 & 1 & 0.296 & 6 \\
\hline NPP, SST, silicate & 7587 & 678 & 0.00 & 8 & 29025 & 1125 & 0.00 & 4 & 0.287 & 2 \\
\hline Clouds, SST, silicate & 7427 & 518 & 0.00 & 6 & 28393 & 493 & 0.00 & 2 & 0.294 & 4 \\
\hline NPP, clouds & 7336 & 427 & 0.00 & 5 & 29404 & 1504 & 0.00 & 8 & 0.302 & 11 \\
\hline NPP, SST & 7661 & 752 & 0.00 & 11 & 30941 & 3041 & 0.00 & 12 & 0.300 & 8 \\
\hline NPP, silicate & 7689 & 780 & 0.00 & 12 & 29387 & 1487 & 0.00 & 7 & 0.302 & 12 \\
\hline Clouds, SST & 7625 & 716 & 0.00 & 9 & 29723 & 1823 & 0.00 & 9 & 0.301 & 10 \\
\hline Clouds, silicate & 7427 & 518 & 0.00 & 6 & 29264 & 1364 & 0.00 & 5 & 0.300 & 9 \\
\hline SST, silicate & 7781 & 872 & 0.00 & 13 & 31737 & 3837 & 0.00 & 14 & 0.298 & 7 \\
\hline NPP & 7814 & 905 & 0.00 & 14 & 31505 & 3605 & 0.00 & 13 & 0.315 & 16 \\
\hline Clouds & 7625 & 716 & 0.00 & 9 & 30913 & 3013 & 0.00 & 11 & 0.311 & 13 \\
\hline SST & 7930 & 1021 & 0.00 & 16 & 32560 & 4660 & 0.00 & 16 & 0.313 & 14 \\
\hline Silicate & 7819 & 910 & 0.00 & 15 & 31933 & 4033 & 0.00 & 15 & 0.313 & 15 \\
\hline
\end{tabular}

narrow down target areas for multi-species marine habitat conservation within a large geographic extent. Using EENM, predicted foraging habitats for adult females of each species covered a large extent of neritic waters along the Gulf coast. For both species, predicted areas appear to be within previously reported extents predicted using MaxEnt with turtle location data obtained from the Ocean Biogeographic Information System (OBIS; https://obis.org) as input (Grüss et al. 2018). However, despite the similarity in diets for the 2 species (Burke et al. 1993), the intersected areas for both species were relatively small.
There were similarities and dissimilarities in the permutation importance of the predictor variables between the 2 species. For both species, NPP had a comparably high level of importance. For Kemp's ridleys, NPP was the most important variable $(52.9 \%)$, followed by bathymetry (17.1\%) and SST (13.8\%), and the remaining variables received a smaller level of importance $(<10 \%)$. Foraging grounds for loggerheads appear to be influenced by more diverse environmental factors. For loggerheads, NPP accounted for the highest importance $(21.6 \%)$ along with 3 other variables, cloud coverage, SST, and silicate amount, which accounted for about $20 \%$ of impor- 
tance each. This inter-species difference may be linked to the difference in movement patterns during foraging periods. In the GoM, loggerheads from the northern GoM nesting group have been shown to forage in slightly deeper water (33 m, loggerheads; $20 \mathrm{~m}$, Kemp's ridleys) and slightly further from shore than Kemp's ridleys that nested in Mexico and Texas (48 km, loggerheads; 25 km, Kemp's ridleys; Shaver et al. 2013, Hart et al. 2014). Examination of stomach contents indicated Kemp's ridley is a prey specialist that primarily consumes crabs (Shaver 1991). Kemp's ridleys, whose foraging grounds are strongly influenced by site productivity, may continually seek optimal foraging sites and individuals may forage in multiple sites which are geographically apart (Shaver et al. 2013). Loggerheads are considered generalist carnivores and forage more opportunistically on a wider prey base (Tomas et al. 2001, Wallace et al. 2009). Studies have shown that individual loggerheads show fidelity both to their adult foraging grounds (Hawkes et al. 2007, Marcovaldi et al. 2010) and to the prey assemblage upon which they forage (Vander Zanden et al. 2010). The observed difference in the relative importance of NPP for the 2 species likely reflects this difference in foraging behaviors.

The importance of climatic factors, such as SST for both species and cloud cover for loggerheads, agree with satellite telemetry data that foraging turtles avoid lethally cold waters during winter (Hawkes et al. 2007). The importance of silicate (18.9\%) on the distribution of loggerhead foraging habitat may reflect effects of silicate input on productivity of those areas. Within the neritic GoM, the increased silicate amount contributes to the development of plankton communities (Turner et al. 1998) which form the base of the food web in aquatic systems. A simulative study indicated effects of ocean currents on behavior of marine turtles by impacting orientation, energy budget, and identification of foraging areas (Gaspar et al. 2006). Another study using MaxEnt to predict the encounter probability for Kemp's ridleys and loggerheads in the GoM found that variables related to ocean currents made the largest contributions to the model (Grüss et al. 2018). In their results, annual range of ocean current speed contributed $36.3 \%$ for loggerhead and $23.3 \%$ for Kemp's ridley, and maximum annual ocean current speed contributed 23.6\% for loggerhead (Grüss et al. 2018). In our results, the permutation importance of ocean current was relatively low for both species, i.e. $6.3 \%$ for Kemp's ridley and $7.6 \%$ for loggerhead. This difference is likely because our input data are limited within foraging periods. Compared to other variables, such as NPP and
SST, the effects of ocean current on habitat suitability appear to be minor.

Model selection results indicated that foraging habitat selection for both species was influenced by a combination of multiple environmental factors. As a general trend, highly parameterized models fit better; the full model was ranked as either 1st or 2 nd by 2 algorithms (GLM and MARS) for both species and the full model is highly likely the best model among all tested models for GLM. The observed greater fit by the full model suggests that all variables we considered were potentially important in predicting suitable foraging habitat for the 2 species, despite the fact that some variables received a relatively small degree of permutation importance. However, there were variabilities in the model ranks between the 3 algorithms. Model ranks by GLM and MARS were relatively consistent, but differed from those by MaxEnt. Regardless of this discrepancy, less parameterized models, such as single-variable models, commonly received lower ranks by all 3 algorithms.

There are 3 important factors to consider regarding the reliability of model predictions. First, in using SDM to predict suitable habitat, the omission rate depends on the threshold selection. We used a previously recommended threshold method, maximizing the sum of sensitivity and specificity (Liu et al. 2013), but there are a number of other threshold selection methods, such as training data prevalence and maximizing overall accuracy. Selection of a threshold selection method depends on the circumstances whether researchers prefer a conservative (smaller area) or more inclusive (larger area) prediction which may be constrained by data availability, logistics, and application purposes. Second, the predictions for suitable foraging areas were very different by algorithm, as many other studies have demonstrated (e.g. Dormann et al. 2008, Watling et al. 2015). Model choice could be a primary source of prediction errors. This uncertainty associated with the choice of model is a common problem in SDM. In the results from variable selection, GLM and MARS resulted in a similar set of variables, but the predicted suitable foraging areas by these 2 models were very different. Some portions of the predicted foraging areas by MARS appeared unrealistic, as they were in deep, offshore waters in the middle of the GoM (Fig. 4). EENM accounts for such uncertainty associated with algorithms, but caution is advised when a single algorithm is applied. The third consideration is that the reliability of model predictions also depends on species, which was demonstrated in this study. Although the model evaluations by cross-validation showed high prediction 
accuracy for both species, the results from the model evaluations based on the independent datasets were distinctly different: a very low omission rate for Kemp's ridleys and a very high omission rate for loggerheads. This likely resulted from (1) our loggerhead foraging data underrepresenting the nesting loggerhead population in the entire GoM (substantially more turtles tagged in DRTO), (2) higher individual variability in foraging site selection by loggerheads, or (3) both. Notably, loggerhead nesting sites span a larger geographical extent along the GoM coast and compared to Kemp's ridleys (Fig. 2). The number of nesting turtles between the 2 species are also different. It was reported that $>25000$ loggerhead nests are observed annually between 1989 and 2006 in surveys along Florida Index Beaches, and $8.6 \%$ of them were in northwest and southwest Florida along the GoM (Witherington et al. 2009). The observed number of nests of Kemp's ridleys is much smaller. Between 1978 and 2014, 1667 Kemp's ridley's nests were documented in Texas (Shaver et al. 2016b). Because of the differences in the sizes of nesting habitats and populations, despite the equal number of tagged turtles for both species ( $\mathrm{n}=63$ ), our sampled turtles unlikely represented both species equally.

Previous telemetry studies also revealed dynamic migratory movements of loggerheads in coastal and oceanic waters, whereas Kemp's ridleys tend to migrate along the coast eastward to reach foraging grounds and westward to return to the nesting beaches (Hart et al. 2014, Shaver et al. 2013, 2016a). Considering the larger habitat extent and population size combined with greater individual variability in migration behavior of loggerheads, our data may be insufficient to predict the foraging extent of the entire nesting loggerhead population in the GoM. Our current input data for loggerheads were from nesting turtles tagged on 4 beaches along the GoM. Incorporating tracking data from additional loggerheads from different nesting sites may help to produce more robust predictions of suitable foraging areas for this species. In this study we did not implement the model or subset the validation data for an assessment by nesting beach because we did not have a representative number of tracked turtles from all beaches. However, considering the observed genetic variations in the loggerhead population in west Florida (Shamblin et al. 2015), with a sufficient number of tracked turtles, modeling the foraging habitat by nesting beaches or each genetic group and evaluating the predictive accuracy may provide further insight on foraging site selection of loggerheads. A previous study has predicted spatial and temporal variation in the distribution of oceanicstage juvenile Kemp's ridleys, loggerheads, and green turtles Chelonia mydas using simulated dispersal patterns for hatchling cohorts originating in each nesting beach based on Global Hybrid Coordinate Ocean Model (HYCOM) hindcasts (Chassignet et al. 2009, Putman et al. 2020). Use of such a simulated dispersal model to predict foraging-site selection of adult sea turtles in conjunction with SDM is worth exploring to improve predictions.

Our results clearly delineated relatively small common foraging areas used by both species along the northern Gulf, western Florida, and the coast of the Yucatán Peninsula (Fig. 3C), which agree with the highly fused foraging habitats by individual turtles using satellite location data (Shaver et al. 2013, Hart et al. 2014, Gredzens \& Shaver 2020). The approach we used may also be extended to identify common inter-nesting habitats and migratory corridors of the 2 species which were previously identified using satellite telemetry data (Hart et al. 2014, Shaver et al. 2016a). The identified common foraging habitats are highly productive, biodiverse areas but they also suffer intense human disturbances. A study demonstrated potential for interactions of nesting female loggerheads and Kemp's ridleys in the GoM with anthropogenic activities such as offshore drilling, shrimp trawling, and oil spills (Hart et al. 2014, 2018). Since adult survival rate is an important factor in population persistence and recovery, such interactions with threats may negatively impact the population. In the present study, we considered only environmental variables to model suitable foraging grounds, but a previous study indicated that human pressure is a strong predictor of geographic range size for terrestrial mammal species (Di Marco \& Santini 2014). Inclusion of human disturbances in ocean habitats may further improve the prediction of suitable foraging areas for marine species and such studies could provide important conservation implications.

Acknowledgements. Deployment of transmitters on loggerheads was authorized under Marine Turtle Permits 118 and 176, US Fish and Wildlife Service Threatened and Endangered Species permit TE-206903-1, Dry Tortugas Scientific permits DRTO-2008-SCI-0008, DRTO-2010-SCI-0009, DRTO-2012, SCI-0008, and US Geological Survey (USGS) Animal Care and Use permit SESC-2011-05. Deployment of transmitters on Kemp's ridleys was authorized under US Fish and Wildlife Service Agreement No. 20181-A-J819 and permit TE840727-3, Texas Parks and Wildlife Department Scientific Permits SPR-0190-122 and SPR-0790-004, Institutional Animal Care Protocol NPS IACUC 2011-15, Secretaría de Medio Ambiente y Recursos Naturales, Subsecretaría de Gestión para la Protección Ambiental, Dirección 
General de Vida Silvestre Permiso No. SGPA/DGVS/03990/ 11, and SEMARNAT-Dirección General de Vida Silvestre Permiso No. SGPA/DGVS/05559/14. Funding for this work was provided by the National Park Service (NPS), USGS Priority Ecosystem Studies program, USGS Ecosystems Program, Deepwater Horizon Natural Resource Damage Assessment (NRDA), and National Fish and Wildlife Foundation. Acuario de Veracruz, Campamento Tortuguero de Rancho Nuevo, Campamento Tortuguero del Totonacapan, Campamento Tortuguero Vida Milenaria, Conservación y Desarollo de Espacios Naturales S.C., Gladys Porter Zoo, and University of Florida provided equipment or logistical assistance. H. R. Chenge Alvarez, J. A. Gallegos Enríquez, D. Gomez Gamez, M. Hernández Hernández, F. Illescas Martínez, H. J. Martínez, J. Ortiz, R. Sánchez Posadas, and others helped deploy transmitters on Kemp's ridleys. T. Clapp, T. Selby, and H. Crowell helped prepare data for analysis and J. Beerens, C. Gredzens, and D. Burkholder reviewed the manuscript. We acknowledge the use of the satellite-tracking and analysis tool (STAT) and telemetry data generated as part of the Deepwater Horizon NRDA (publicly available from www.seaturtle.org). References to non-NPS and non-USGS products and services are provided for information only and do not constitute endorsement or warranty, expressed or implied, by the US Government, as to their suitability, content, usefulness, functioning, completeness, or accuracy. Any use of trade, product, or firm names is for descriptive purposes only and does not imply endorsement by the US Government.

\section{LITERATURE CITED}

Allouche O, Tsoar A, Kadmon R (2006) Assessing the accuracy of species distribution models: prevalence, kappa and the true skill statistic (TSS). J Appl Ecol 43:1223-1232

Araújo MB, New M (2006) Ensemble forecasting of species distributions. Trends Ecol Evol 22:42-47

Bailey H, Shillinger G, Palaciosa D, Bograd S, Spotila J, Paladino F, Block B (2008) Identifying and comparing phases of movement by leatherback turtles using statespace models. J Exp Mar Biol Ecol 356:128-135

Bjorndal KA, Jackson JBC (2003) Roles of sea turtles in marine ecosystems: reconstructing the past. In: Lutz PL, Musick JA, Wyneken J (eds) The biology of sea turtles. CRC Press, Boca Raton, FL, p 259-274

Boykin KG, Bradford DF, Kepner WG (2008) Habitat distribution models for 37 vertebrate species in the Mojave Desert ecoregion of Nevada, Arizona, and Utah. EPA/ 600/R-08/117. US Environmental Protection Agency, Office of Research and Development

Breed GA, Jonsen ID, Myers RA, Bowen WD, Leonard ML (2009) Sex-specific, seasonal foraging tactics of adult grey seals (Halichoerus grypus) revealed by state-space analysis. Ecology 90:3209-3221

*Burke VJ, Standora EA, Morreale SJ (1993) Diet of juvenile Kemp's ridley and loggerhead sea turtles from Long Island, New York. Copeia 1993:1176-1180

Burnham KP, Anderson DR (2002) Model selection and multimodel inference: a practical information-theoretic approach. Springer, New York, NY

Cayula JF, Cornillon P (1992) Edge detection algorithm for SST images. J Atmos Ocean Technol 9:67-80

* Chape S, Harrison J, Spalding M, Lysenko I (2005) Measuring the extent and effectiveness of protected areas as an indicator for meeting global biodiversity targets. Philos Trans R Soc B 360:443-455
Chassignet EP, Hurlburt HE, Metzger EJ, Smedstad OM and others (2009) US GODAE: global ocean prediction with the HYbrid Coordinate Ocean Model (HYCOM). Oceanography (Wash DC) 22:64-75

* Di Marco M, Santini L (2014) Human pressures predict species' geographic range size better than biological traits. Glob Change Biol 21:2169-2178

* Dobson AP, Rodriguez JP, Roberts WM, Wilcove DS (1997) Geographic distribution of endangered species in the United States. Science 275:550-553

* Dormann CF, Purschke O, Márquez G, Lautenbach S, Schröder B (2008) Components of uncertainty in species distribution analysis: a case study of the great gray shrike. Ecology 89:3371-3386

Elith J, Leathwick JR (2009) Species distribution models: ecological explanation and prediction across space and time. Annu Rev Ecol Evol Syst 40:677-697

Fielding AH, Bell JF (1997) A review of methods for the assessment of prediction errors in conservation presence/ absence models. Environ Conserv 24:38-49

Fleiss JL, Cohen J (1973) The equivalence of weighted kappa and the intraclass correlation coefficient as measures of reliability. Educ Psychol Meas 33:613-619

Franklin J (2013) Species distribution models in conservation biogeography. Divers Distrib 19:1217-1223

*Gaspar P, Georges JY, Fossette S, Lenoble A, Ferraroli S, Le Maho Y (2006) Marine animal behaviour: Neglecting ocean currents can lead us up the wrong track. Proc R Soc B 273:2697-2702

*Godley BJ, Blumenthal JM, Broderick AC, Coyne MS, Godfrey MH, Hawkes LA, Witt MJ (2008) Satellite tracking of sea turtles: Where have we been and where do we go next? Endang Species Res 4:3-22

*Gredzens C, Shaver DJ (2020) Satellite tracking can inform population-level dispersal to foraging grounds of postnesting Kemp's ridley sea turtles. Front Mar Sci 7:559

Griffin DB, Murphy SR, Frick MG, Broderick AC and others (2013) Foraging habitats and migration corridors utilized by a recovering subpopulation of adult female loggerhead sea turtles: implications for conservation. Mar Biol 160:3071-3086

* Grüss A, Drexler MD, Ainsworth CH, Roberts JJ and others (2018) Improving the spatial allocation of marine mammal and sea turtle biomasses in spatially explicit ecosystem models. Mar Ecol Prog Ser 602:255-274

Guisan A, Zimmermann NE (2000) Predictive habitat distribution models in ecology. Ecol Modell 135:147-186

Guisan A, Tingley R, Baumgartner JB, Naujokaitis-Lewis I and others (2013) Predicting species distributions for conservation decisions. Ecol Lett 16:1424-1435

*Hart KM, Lamont MM, Fujisaki I, Tucker AD, Carthy RR (2012) Common coastal foraging areas for loggerheads in the Gulf of Mexico: opportunities for marine conservation. Biol Conserv 145:185-194

* Hart KM, Lamont MM, Sartain AR, Fujisaki I (2014) Migration, foraging, and residency patterns for northern Gulf loggerheads: implications of local threats and international movements. PLOS ONE 9:e103453

*Hart KM, Iverson AR, Fujisaki I, Lamont MM, Bucklin D, Shaver DJ (2018) Marine threats for two imperiled sea turtle species in the Gulf of Mexico. Front Mar Sci 5:336

*Hawkes LA, Broderick AC, Coyne MS, Godfrey MH, Godley BJ (2007) Only some like it hot: quantifying the environmental niche of the loggerhead sea turtle. Divers Distrib 13:447-457

* Hoenner X, Whiting SD, Hindell MA, McMahon CR (2012) Enhancing the use of Argos satellite data for home range 
and long distance migration studies of marine animals. PLOS ONE 7:e40713

Jonsen ID, Myers RA, Flemming JM (2003) Meta-analysis of animal movement using state-space models. Ecology 84: 3055-3063

* Jonsen ID, Flemming JM, Myers RA (2005) Robust statespace modeling of animal movement data. Ecology 86: 2874-2880

Jonsen ID, Myers RA, James MC (2006) Robust hierarchical state-space models reveal diel variation in travel rates of migrating leatherback turtles. J Anim Ecol 75: 1046-1057

Jonsen ID, Myers RA, James MC (2007) Identifying leatherback turtle foraging behavior from satellite telemetry using a switching state-space model. Mar Ecol Prog Ser 337:255-264

Landis JR, Koch GG (1977) The measurement of observer agreement for categorical data. Biometrics 33:159-174

Liu C, White M, Newell G (2013) Selecting thresholds for prediction of species occurrence with presence-only data. J Biogeogr 40:779-789

* Mansfield K, Saba V, Keinath J, Musick J (2009) Satellite tracking reveals a dichotomy in migration strategies among juvenile loggerhead turtles in the Northwest Atlantic. Mar Biol 156:2555-2570

* Marcovaldi M, Lopez G, Soares L, Lima E, Thomé J, Almeida A (2010) Satellite-tracking of female loggerhead turtles highlights fidelity behavior in northeastern Brazil. Endang Species Res 12:263-272

Mazor T, Beger M, McGowan J, Possingham HP, Kark A (2016) The value of migration information for conservation prioritization of sea turtles in the Mediterranean. Glob Ecol Biogeogr 25:540-552

McKee JK, Sciulli PW, Fooce CD, Waite TA (2004) Forecasting global biodiversity threats associated with human population growth. Biol Conserv 115:161-164

Myers N, Mittermeier RA, Mittermeier CG, da Fonseca GAB, Kent J (2000) Biodiversity hotspots for conservation priorities. Nature 403:853-858

NMFS SEFSC (2008) Southeast fisheries science center sea turtle research techniques manual. US National Marine Fisheries Service, Miami, FL

* Patterson TA, Thomas L, Wilcox C, Ovaskainen O, Matthiopoulos J (2008) Statespace models of individual animal movement. Trends Ecol Evol 23:87-94

Phillips SJ, Anderson RP, Schapire RE (2006) Maximum entropy modeling of species geographic distributions. Ecol Modell 190:231-259

* Piacenza SE, Thurman LL, Barner AK, Benkwitt CE and others (2015) Evaluating temporal consistency in marine biodiversity hotspots. PLOS ONE 10:e0133301

Pike DA (2013) Climate influences the global distribution of sea turtle nesting. Glob Ecol Biogeogr 22:555-566

Pike DA (2014) Forecasting the viability of sea turtle eggs in a warming world. Glob Change Biol 20:7-15

* Pikesley SK, Maxwell SM, Pendoley K, Costa DP and others (2013) On the front line: integrated habitat mapping for olive ridley sea turtles in the southeast Atlantic. Divers Distrib 19:1518-1530

* Pikesley SK, Broderick AC, Cejudo D, Coyne MS and others (2015) Modelling the niche for a marine vertebrate a case study incorporating behavioural plasticity, proximate threats and climate change. Ecography 38:803-812

Pollock LJ, Tingley R, Morris WK, Golding N and others (2014) Understanding co-occurrence by modelling species simultaneously with a Joint Species Distribution Model (JSDM). Methods Ecol Evol 5:397-406
Putman NF, Seney EE, Verley P, Shaver DJ and others (2020) Predicted distributions and abundances of the sea turtle 'lost years' in the western North Atlantic Ocean. Ecography 43:506-517

* Roberts JJ, Best BD, Dunn DC, Treml EA, Halpin PN (2010) Marine geospatial ecology tools: an integrated framework for ecological geoprocessing with ArcGIS, Python, R, MATLAB, and C++. Environ Model Softw 25:1197-1207

* Seney EE, Landry AM (2011) Movement patterns of immature and adult female Kemp's ridley sea turtles in the northwestern Gulf of Mexico. Mar Ecol Prog Ser 440:241-254

Shamblin BM, Bagley DA, Ehrhart LM, Desjardin NA and others (2015) Genetic structure of Florida green turtle rookeries as indicated by mitochondrial DNA control region sequences. Conserv Genet 16:673-685

Shaver DJ (1991) Feeding ecology of wild and head-started Kemp's ridleys in South Texas waters. J Herpetol 25: 327-334

* Shaver DJ, Rubio C (2008) Post-nesting movement of wild and head-started Kemp's ridley sea turtles Lepidochelys kempii in the Gulf of Mexico. Endang Species Res 4:43-55

* Shaver DJ, Hart KM, Fujisaki I, Rubio C and others (2013) Foraging area fidelity for Kemp's ridleys in the Gulf of Mexico. Ecol Evol 3:2002-2012

Shaver DJ, Hart KM, Fujisaki I, Rubio C and others (2016a) Migratory corridors of adult female Kemp's ridley turtles in the Gulf of Mexico. Biol Conserv 194:158-167

* Shaver DJ, Rubio C, Walker JS, George J, Amos AF (2016b) Kemp's ridley sea turtle (Lepidochelys kempii) nesting on the Texas coast: geographic, temporal, and demographic trends through 2014. Gulf Mex Sci 33:158-178

* Soulé ME (1991) Conservation: tactics for a constant crisis. Science 253:744-750

Stokes KL, Broderick AC, Canbolat AF, Candan O and others (2015) Migratory corridors and foraging hotspots: critical habitats identified for Mediterranean green turtles. Divers Distrib 21:665-674

* Swets J (1988) Measuring the accuracy of diagnostic systems. Science 240:1285-1293

* Thuiller W, Georges D, Engler R, Breiner F (2016) biomod2: ensemble platform for species distribution modeling. $\mathrm{R}$ package version 3.3-7. https://CRAN.R-project.org/ package=biomod2

Tomas J, Aznar FJ, Raga JA (2001) Feeding ecology of the loggerhead turtle Caretta caretta in the western Mediterranean. J Zool (Lond) 255:525-532

* Turner RE, Qureshi N, Rabalais NN, Dortch Q, Justić D, Shaw RF, Cope J (1998) Fluctuating silicate:nitrate ratios and coastal plankton food webs. Proc Natl Acad Sci USA 95:13048-13051

* Tyberghein L, Verbruggen H, Pauly K, Troupin C, Mineur F, De Clerck O (2012) Bio-ORACLE: a global environmental dataset for marine species distribution modelling. Glob Ecol Biogeogr 21:272-281

Vander Zanden HB, Bjorndal KA, Reich KJ, Bolten AB (2010) Individual specialists in a generalist population: results from a long-term stable isotope series. Biol Lett 6:711-714

*Wallace BP, Avens L, Braun-McNeill J, McClellan CM (2009) Diet composition of immature loggerheads: insights on trophic niche, growth rates and fisheries interactions. J Exp Mar Biol Ecol 373:50-57

*Wallace BP, DiMatteo AD, Bolten AB, Chaloupka MY and others (2011) Global conservation priorities for marine turtles. PLOS ONE 6:e24510

* Watling JI, Brandt LA, Bucklin DN, Fujisaki I, Mazzotti FJ, Romañach SS, Speroterra C (2015) Performance metrics 
and variance partitioning reveal sources of uncertainty in species distribution models. Ecol Modell 309-310:48-59 Wilson AM, Jetz W (2016) Remotely sensed high-resolution global cloud dynamics for predicting ecosystem and biodiversity distributions. PLOS Biol 14:e1002415

Wilson KA, McBride MF, Bode M, Possingham HP (2006) Prioritizing global conservation efforts. Nature 440:337-340

Editorial responsibility: Paolo Casale,

Pisa, Italy
Winton MV, Fay G, Haas HL, Arendt M and others (2018) Estimating the distribution and relative density of satellite-tagged loggerhead sea turtles using geostatistical mixed effects models. Mar Ecol Prog Ser 586:217-232

* Witherington B, Kubilis P, Brost B, Meylan A (2009) Decreasing annual nest counts in a globally important loggerhead sea turtle population. Ecol Appl 19:30-54

Submitted: January 7, 2020; Accepted: July 8, 2020

Proofs received from author(s): October 6, 2020 